Article

\title{
Effect of Niobium Addition on the High-Temperature Oxidation Behavior of 22Cr25NiWCoCu Stainless Steel in Air
}

\author{
Sheng-Yao Huang ${ }^{1}$, Wen-Ta Tsai ${ }^{1}$, Yeong-Tsuen Pan ${ }^{2}$, Jui-Chao Kuo ${ }^{1, *}$, Hsien-Wei Chen ${ }^{3}$ \\ and Dong-Yih Lin ${ }^{4}$ \\ 1 Department of Materials Science and Engineering, National Cheng-Kung University, Tainan 701, Taiwan \\ 2 New Materials Research \& Development Department, China Steel Corporation, Kaohsiung City 812, Taiwan \\ 3 Department of Materials Science and Engineering, City University of Hong Kong, 4/F Fong Yun Wah \\ Building, Tat Chee Avenue, Kowloon 999077, Hong Kong, China \\ 4 Department of Chemical and Materials Engineering, National University of Kaohsiung, \\ Kaohsiung City 811, Taiwan \\ * Correspondence: jckuo@mail.ncku.edu.tw; Tel.: +886-6-2757575 (ext. 62939)
}

Received: 22 August 2019; Accepted: 30 August 2019; Published: 3 September 2019

\begin{abstract}
The oxidation behavior of $22 \mathrm{Cr} 25 \mathrm{NiWCoCu}$ stainless steel with $0-0.86 \mathrm{wt} . \% \mathrm{Nb}$ addition was investigated at $900^{\circ} \mathrm{C}$ in air. With an increase in $\mathrm{Nb}$ addition, the volume fraction and average particle size of $\mathrm{Nb}(\mathrm{C}, \mathrm{N})$ increased, but the grain size decreased. The results of grazing incidence $\mathrm{X}$-ray diffraction indicated that the steels with $\mathrm{Nb}$ additions promoted $\mathrm{Cr}_{2} \mathrm{O}_{3}$ formation. After 10-100 $\mathrm{h}$ of oxidation, $\mathrm{Cr}$ depletion occurred at the region with $\mathrm{Nb}(\mathrm{C}, \mathrm{N})$ precipitates because of its high $\mathrm{Cr}$ consumption rate, leading to Fe oxide generation. Finally, after $100 \mathrm{~h}$ of oxidation, the outer layer of $\mathrm{Fe}_{2} \mathrm{O}_{3}$ and the inner layer of $(\mathrm{Cr}, \mathrm{Fe}, \mathrm{Mn})_{3} \mathrm{O}_{4}$ were formed.
\end{abstract}

Keywords: oxidation; austenitic stainless steel; $\mathrm{Nb}(\mathrm{C}, \mathrm{N})$; nodule; EBSD

\section{Introduction}

According to a global energy report from the International Energy Agency, the amount of $\mathrm{CO}_{2}$ emissions increased from 23 gigatons (Gt) to $32.5 \mathrm{Gt}$ from 2000 to 2017 [1]. Reducing $\mathrm{CO}_{2}$ emissions is necessary to decrease their impact on the environment. $\mathrm{CO}_{2}$ emission is generally reduced in two ways: one is to improve thermal efficiency, and the other is to capture $\mathrm{CO}_{2}$ from the end-of-pipe fuel gas [2]. Given that thermal efficiency can be improved by increasing the working temperature, the materials applied as parts of power generators may face harsh working conditions such as high temperatures $\left(700-760^{\circ} \mathrm{C}\right.$ ) and high steam pressures (30-35 MPa). Accordingly, the materials must have good high-temperature mechanical properties and oxidation resistance. In general, the best candidate materials are Ni-based superalloys (for example, Inconel and Incoloy alloys) because of their superior mechanical properties (tensile stress and creep resistance) and corrosion resistance (hot corrosion and high-temperature oxidation); however, their costs are also relatively high. Thus, austenitic stainless steels with high chromium (Cr, 16-30 wt.\%) and nickel (Ni, > 20\%) content should be the focus in the development of high-temperature applicable materials.

Alloys with high $\mathrm{Cr}$ content, such as AISI $310 \mathrm{SS}$ and $20 \mathrm{Cr}-25 \mathrm{Ni}-\mathrm{Nb}$ stabilized stainless steel, were chosen to improve the high oxidation resistance because they form a protective $\mathrm{Cr}_{2} \mathrm{O}_{3}$ oxide layer [3,4]. Sanicro 25, a $\mathrm{Nb}$-containing austenitic stainless steel with a high-temperature oxidation resistance, was recently developed [5]. Thereafter, the oxidation behaviors of Sanicro 25 have been reported [6-10]. In studies by Intiso et al. [6,7], a thin protective oxide layer was observed in a dry environment $\left(\mathrm{N}_{2}-5 \% \mathrm{O}_{2}\right)$ between $600-750{ }^{\circ} \mathrm{C}$ for $168 \mathrm{~h}$ and in a wet environment $\left(\mathrm{N}_{2}-5 \% \mathrm{O}_{2}-10 \%\right.$ 
$\mathrm{H}_{2} \mathrm{O}$ ) at $600{ }^{\circ} \mathrm{C}$, but local breakaway oxidation was observed when the temperature was between 700 and $750{ }^{\circ} \mathrm{C}$. Zurek et al. conducted oxidation experiments for Sanicro 25 in Ar-50\% $\mathrm{H}_{2} \mathrm{O}$ between $600-750{ }^{\circ} \mathrm{C}$, and its oxidation rate was slightly faster than that of alloy 617 at 600,650 , and $700{ }^{\circ} \mathrm{C}$ because a strong protective $\mathrm{Cr}_{2} \mathrm{O}_{3}$ layer formed; otherwise, an outer oxide layer enriched with $\mathrm{Fe}$ and $\mathrm{Ni}$ was observed at $750{ }^{\circ} \mathrm{C}$ [8]. In Rutkowski et al.'s studies, $\mathrm{Cr}_{2} \mathrm{O}_{3}$ had been observed in a $600{ }^{\circ} \mathrm{C}$ gas mixture [9] and a $700{ }^{\circ} \mathrm{C}$ water vapor environment [10]. Despite the good oxidation resistance of Sanicro 25 at $600-750{ }^{\circ} \mathrm{C}$, discussions of the effect of $\mathrm{Nb}$ or its precipitates on the oxidation behaviors remain scarce. In an earlier study of the oxidation of $20 \mathrm{Cr}-25 \mathrm{Ni}-\mathrm{Nb}$ stabilized SS, Allen et al. revealed that $\mathrm{Nb}(\mathrm{C}, \mathrm{N})$ transformed into coarsened carbonitride $\mathrm{Nb}_{3} \mathrm{M}_{3}(\mathrm{C}, \mathrm{N})$ and promoted the formation of $\mathrm{M}_{2} \mathrm{O}_{3}$ during exposure to 50 Torr $\mathrm{CO}_{2}$ at $800{ }^{\circ} \mathrm{C}$ for $15 \mathrm{~min}$; a mound (nodule) was observed where the reaction occurred [11,12]. However, no further discussion was conducted about the following oxidation behaviors affected by $\mathrm{Nb}$ precipitates.

In our previous study, the microstructure of $22 \mathrm{Cr} 25 \mathrm{NiWCoCu}-\mathrm{xNb}$ stainless steel with a modified $\mathrm{Nb}$ content from $0-0.86 \mathrm{wt} . \%$ was investigated. The results showed that the average grain size was reduced with increasing $\mathrm{Nb}$ content, and the volume fraction and particle size of the precipitates were also changed [13]. A reduction in grain size is beneficial in oxidation resistance because the grain boundaries act as fast diffusion paths for $\mathrm{Cr}$ to form a protective $\mathrm{Cr}_{2} \mathrm{O}_{3}$ layer [14-18]. Otherwise, some phenomena, such as different morphologies of the oxides, could possibly be induced by the precipitates [18-20]. These occurrences have not been mentioned in these reports, and the effects caused by the precipitates during oxidation still require further investigation.

In this work, we conducted an oxidation test for $22 \mathrm{Cr} 25 \mathrm{NiWCoCu}-\mathrm{xNb}$ stainless steel at $900{ }^{\circ} \mathrm{C}$ in air to accelerate the process and reduce the required time. Thermal gravimetric analysis (TGA) was employed to investigate oxidation kinetics. The specimens oxidized by atmospheric furnace were used to observe the formation of corrosion products over time. Grazing incidence X-ray diffraction (GI-XRD) was applied to identify the oxides formed on the surface, and the software TOPAS was used to calculate the fractions of $\mathrm{Cr}_{2} \mathrm{O}_{3}, \mathrm{M}_{3} \mathrm{O}_{4}$, and $\mathrm{Fe}_{2} \mathrm{O}_{3}$. Scanning electron microscopy (SEM) was employed to analyze the microstructures on the surface and the cross-sections of the oxide layer. Electron backscatter diffraction (EBSD) can be applied in the analysis of the oxide scale, as proven by Higginson et al. [21-23]. Kim et al. also used EBSD to examine the oxide scales of 304 stainless steels $[17,24]$. In the present study, EBSD was employed to analyze the orientation and phase distribution of the oxide scales, and energy-dispersive $X$-ray spectroscopy (EDS) was applied to help distinguish $\mathrm{Cr}_{2} \mathrm{O}_{3}$ and $\mathrm{Fe}_{2} \mathrm{O}_{3}$ in the oxide layer.

\section{Experiment and Method}

\subsection{Materials and Sample Preparation}

The chemical compositions of the steels studied are listed in Table 1. The steels were melted based on the major compositions of the commercial Sanicro 25 steel with varying amounts of $\mathrm{Nb}$. The nitrogen content of the molten metal was analyzed using an oxygen and nitrogen elemental analyzer (HORIBA EMGA-920 O/N analyzer), and the other alloying elements were analyzed by an inductively coupled plasma atomic emission spectroscope ARL-4460 Metals Analyzer (Thermo Fisher Scientific, Waltham, MA, USA). The materials were produced using a vacuum induction-melting furnace. The ingot was hot rolled at $1250{ }^{\circ} \mathrm{C}$ and finished at an end-rolling temperature of $950{ }^{\circ} \mathrm{C}$ with a final reduction ratio of $85 \%$. The hot-rolled plate was normalized at $1050{ }^{\circ} \mathrm{C}$ for $30 \mathrm{~min}$ to remove residual stress and annealed at $1300{ }^{\circ} \mathrm{C}$ for $2 \mathrm{~h}$ to ensure that the steel microstructure was homogenous.

The specimens for the oxidation experiments with dimensions of $14 \times 9 \times 1 \mathrm{~mm}^{3}$ were cut from the as-annealed plates, and a hole with a diameter of $1 \mathrm{~mm}$ was subsequently drilled at the top of the specimen for suspension. The prepared specimens were ground with $\mathrm{SiC}$ abrasive paper up to \#1200 and ultrasonically cleaned with acetone and ethanol. The specimens were then suspended in a ceramic 
crucible with a platinum wire for the oxidation tests conducted by TGA and by the atmospheric box furnace.

Table 1. Chemical composition of $22 \mathrm{Cr} 25 \mathrm{NiWCoCu}$ stainless steels with $0-0.86 \mathrm{wt} . \% \mathrm{Nb}$.

\begin{tabular}{|c|c|c|c|c|c|c|c|c|c|c|c|c|c|}
\hline Specimen & $\mathrm{Fe}$ & $\mathrm{Cr}$ & $\mathbf{N i}$ & $\mathbf{W}$ & $\mathrm{Cu}$ & Co & $\mathbf{N}$ & $\mathrm{C}$ & $\mathbf{S i}$ & $\mathrm{Mn}$ & $\mathbf{P}$ & $S$ & $\mathrm{Nb}$ \\
\hline $0-\mathrm{Nb}$ & Bal. & 22.20 & 24.40 & 3.39 & 2.90 & 1.47 & 0.23 & 0.07 & 0.19 & 0.49 & 0.009 & 0.005 & 0 \\
\hline $0.29-\mathrm{Nb}$ & Bal. & 22.10 & 24.30 & 3.40 & 2.90 & 1.49 & 0.23 & 0.07 & 0.19 & 0.49 & 0.01 & 0.005 & 0.29 \\
\hline $0.58-\mathrm{Nb}$ & Bal. & 21.90 & 24.20 & 3.36 & 2.90 & 1.45 & 0.23 & 0.07 & 0.20 & 0.49 & 0.01 & 0.005 & 0.58 \\
\hline $0.86-\mathrm{Nb}$ & Bal. & 21.80 & 24.10 & 3.52 & 2.90 & 1.54 & 0.23 & 0.07 & 0.20 & 0.49 & 0.01 & 0.005 & 0.86 \\
\hline
\end{tabular}

\subsection{High-Temperature Oxidation Tests}

Continuous isothermal weight changes were analyzed using TGA (NETZSCH STA 449 F3 Jupiter ${ }^{\circledR}$, Selb, Germany). The samples were suspended in a ceramic crucible with a platinum wire. The chamber was heated to $900{ }^{\circ} \mathrm{C}$ with a heating rate of $40{ }^{\circ} \mathrm{C} / \mathrm{min}$ and then held for $150 \mathrm{~h}$ with a gas flow of $100 \mathrm{~mL} / \mathrm{min}$ (laboratory air, $0.21 \mathrm{~atm}$ oxygen partial pressure).

Specimens for the observation of oxides were exposed to the ambient atmosphere, suspended in the ceramic crucible with a platinum wire, and directly placed into the atmospheric furnace preheated to $900{ }^{\circ} \mathrm{C}$ with exposure times of $1,10,25,50,75,100$, and $150 \mathrm{~h}$. The specimens with the crucible were then removed from the furnace and air cooled at the end of the exposure. The weight change of the oxidized specimens was measured with an electronic balance $( \pm 0.01 \mathrm{mg})$.

GI-XRD (Bruker D8 Advance Series II, Bremen, Germany) was employed for the phase identification of oxidation products at $2^{\circ} \mathrm{X}$-ray incidence angle. GI-XRD results were analyzed by using the software TOPAS for calculating the ratio of phases. The microstructure characterization was examined by the backscattered electron mode of the SEM (Hitachi SU-1500, Hitachi, Tokyo, Japan). The specimens for cross-sectional observation were plated with a nickel layer to avoid damaging the oxide layers during grinding and polishing. Phase distributions and crystallographic orientations of the oxide layer of the specimens oxidized for $150 \mathrm{~h}$ were observed using a Zeiss Supra 55 field-emission electron microscope, together with Oxford Symmetry: Symmetry CMOS Detector (Oxford instrument, High Wycombe, UK) for EBSD data collection with $20 \mathrm{kV}$ accelerating voltage at $12 \mathrm{~mm}$ working distance under $70^{\circ}$ tilt angle. Chemical composition characterization of the oxide layer was conducted using EDS (EDAX, Octane Elect EDS System) at $30 \mathrm{kV}$ accelerating voltage and a $10 \mathrm{~mm}$ working distance.

\section{Results and Discussion}

\subsection{Microstructure Analysis of As-Reannealed Specimens}

Figure 1 shows the optical micrographs of the $22 \mathrm{Cr} 25 \mathrm{NiWCoCu}$ stainless steel specimens with $\mathrm{Nb}$ addition. In the case of $0-\mathrm{Nb}$, no precipitate was observed, and the average grain size was $426 \pm 107 \mu \mathrm{m}$. For $0.29-\mathrm{Nb}$ addition, the average grain size decreased to $146 \pm 25 \mu \mathrm{m}$, and the fine precipitates of $\mathrm{Nb}(\mathrm{C}, \mathrm{N})$ were randomly distributed in the matrix. The average grain size of $0.58-\mathrm{Nb}$ steel was $114 \pm 12 \mu \mathrm{m}$, and the $\mathrm{Nb}(\mathrm{C}, \mathrm{N})$ precipitates were fine and large sized. When the $\mathrm{Nb}$ addition was raised to $0.86 \mathrm{wt} . \%$, the volume fraction of large-sized precipitates of $\mathrm{Nb}(\mathrm{C}, \mathrm{N})$ increased significantly, few fine particles were observed, and the average grain size decreased to $90 \pm 12 \mu \mathrm{m}$.

These results show that when the $\mathrm{Nb}$ addition increases in $22 \mathrm{Cr} 25 \mathrm{NiWCoCu}$ stainless steels, the average grain size decreases, and the precipitates of $\mathrm{Nb}(\mathrm{C}, \mathrm{N})$ tend to cluster. These phenomena were also observed in our previous study [13], in which the fine and coarse precipitates of $\mathrm{Nb}(\mathrm{C}, \mathrm{N})$ simultaneously appeared. The hardness values of the four steels were $210 \mathrm{HV}$, as shown in Table 2 . These results indicated that alloyed $\mathrm{Nb}$ can promote the grain refinement and precipitation of $\mathrm{Nb}(\mathrm{C}$, $\mathrm{N})$, but the hardness of the four steels did not exhibit substantial differences. 

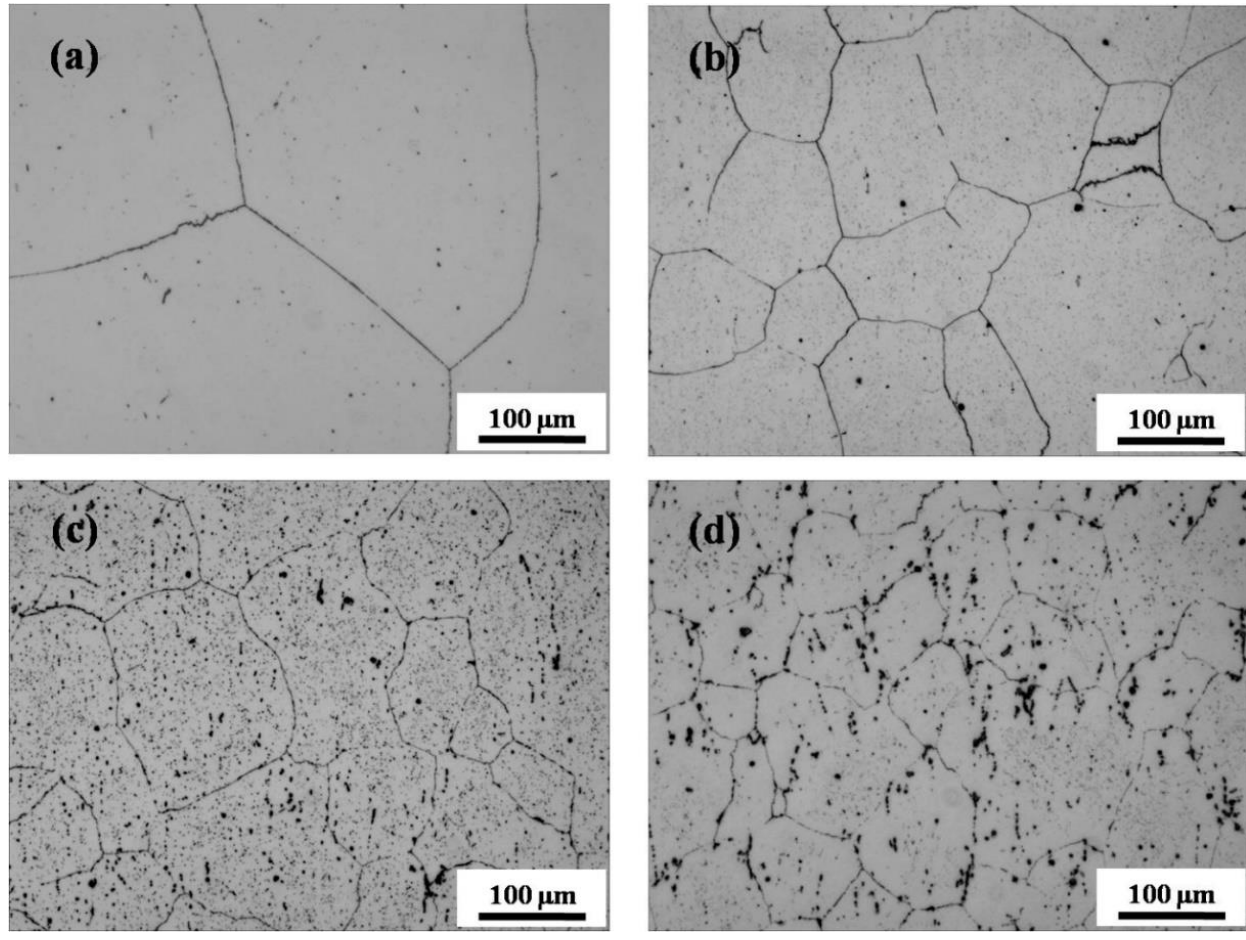

Figure 1. Optical micrograph of $22 \mathrm{Cr} 25 \mathrm{NiWCoCu}$ stainless steels with $\mathrm{Nb}$ contents of (a) 0 , (b) 0.29 , (c) 0.58 , and (d) $0.86 \mathrm{wt} . \%$.

Table 2. Vickers hardness of 22Cr25NiWCoCu stainless steels with $0-0.86 \mathrm{wt} . \% \mathrm{Nb}$.

\begin{tabular}{ccccc}
\hline Specimen & $\mathbf{0 - N b}$ & $\mathbf{0 . 2 9 - N b}$ & $\mathbf{0 . 5 8 - N b}$ & $\mathbf{0 . 8 6}-\mathbf{N b}$ \\
\hline Hardness $(\mathrm{HV})$ & $214.3 \pm 8.2$ & $218.2 \pm 8.4$ & $214.6 \pm 4.6$ & $210.9 \pm 7.4$ \\
\hline
\end{tabular}

\subsection{High-Temperature Oxidation Behavior}

Figure 2 shows the weight gain per unit area for each specimen. Continuous measurements were conducted using TGA to investigate the change in oxides during oxidation. Discontinuous measurements were performed using an atmospheric furnace in the same oxidation conditions, and the discontinuous weight changes of individual specimens were recorded. TGA results are shown in Figure 2a, in which the solid lines represent the continuous weight changes over time, and the dotted lines are the fitting curves using the power law:

$$
\Delta W=\left(K_{P} t\right)^{1 / n}+C,
$$

where $\Delta W$ is the weight gain per unit area; $K_{P}, n$, and $C$ are the constants for the power law; and $t$ is the exposure time. The fitting curves are listed in Table 3. The results show that the oxidation behaviors of $0-\mathrm{Nb}$ and $0.29-\mathrm{Nb}$ steels had $\mathrm{n}$ values of approximately 2 , and those of $0.58-\mathrm{Nb}$ and $0.86-\mathrm{Nb}$ steels had $\mathrm{n}$ values larger than 3 . Furthermore, $0.58-\mathrm{Nb}$ steel had the highest weight gain before $46 \mathrm{~h}$, but $0.86-\mathrm{Nb}$ steel had the highest weight gain after 46 h, which is clearly observed in Figure 2a.

Table 3. Fitting parameters of thermal gravimetric analysis (TGA) data using the power law.

\begin{tabular}{cccc}
\hline Specimen & $\boldsymbol{K}_{\boldsymbol{p}}$ & $\boldsymbol{n}$ & $\boldsymbol{C}$ \\
\hline $0-\mathrm{Nb}$ & 0.08 & 1.86 & 0.54 \\
$0.29-\mathrm{Nb}$ & 0.10 & 1.92 & 0.52 \\
$0.58-\mathrm{Nb}$ & 0.44 & 3.70 & 0.27 \\
$0.86-\mathrm{Nb}$ & 0.44 & 3.08 & 0.32 \\
\hline
\end{tabular}



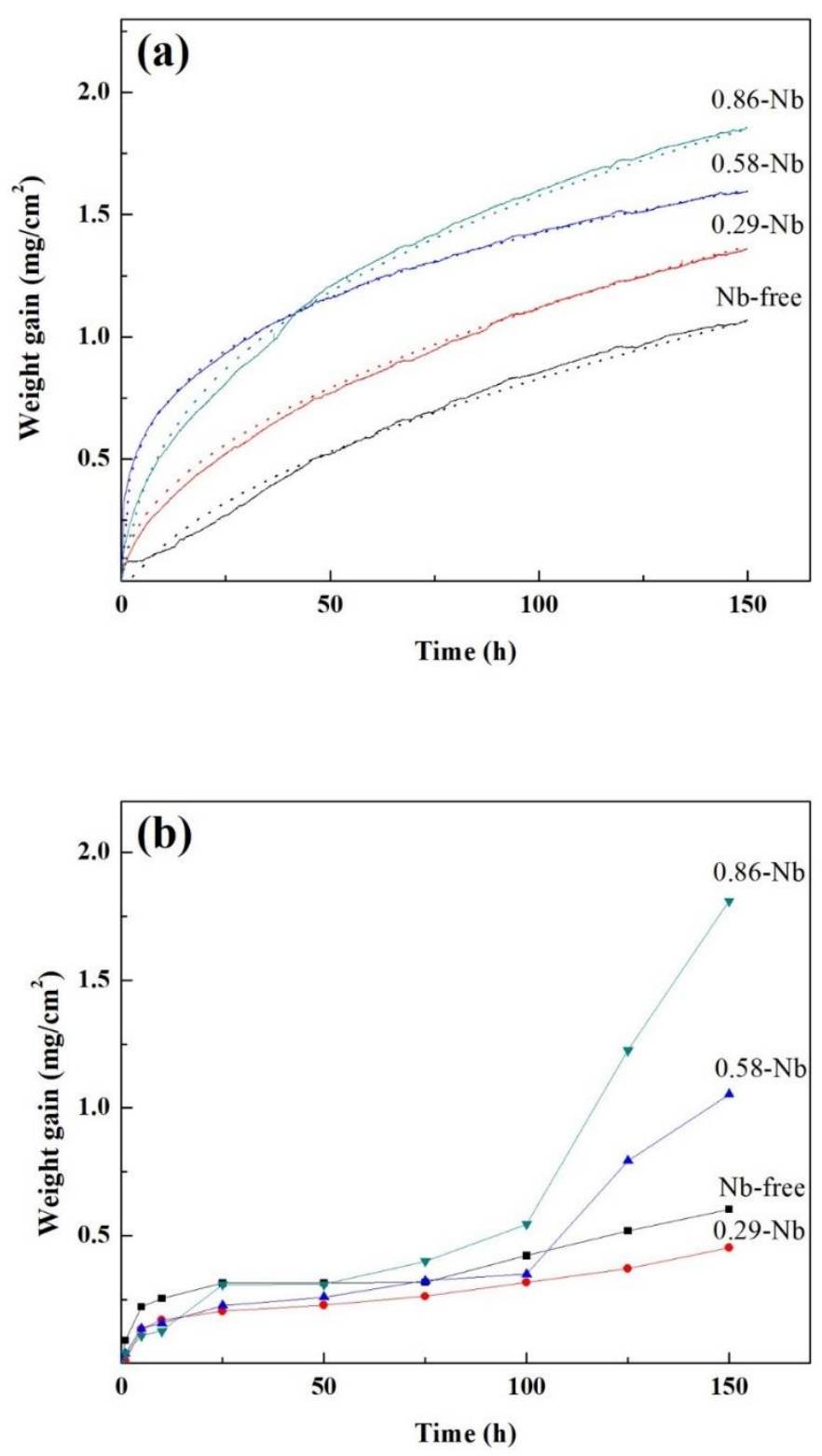

Figure 2. Weight change per unit area as a function of time in 22Cr25NiWCoCu stainless steels with $0-0.86 \% \mathrm{Nb}$ for continuous and discontinuous measurements in (a) thermal gravimetric analysis (TGA) and (b) an atmospheric box furnace, respectively.

Figure $2 \mathrm{~b}$ shows the weight gain per unit area obtained from discontinuous measurements and reveals that all specimens had three oxidation stages. First, a weight gain following the parabolic growth law was observed at $10 \mathrm{~h}$. A low oxidation rate was then reached. Finally, the oxidation rate increased again for $0.58-\mathrm{Nb}$ and $0.86-\mathrm{Nb}$ steels, where the most weight gain can be found in $0.86-\mathrm{Nb}$ steel after $150 \mathrm{~h}$ of oxidation.

Although the test conditions for the continuous and discontinuous measurements obtained from TGA and the atmospheric furnace were similar, the weight gain curves obtained were different, as shown in Figure 2. The same specimens were employed for continuous measurements in TGA, whereas those for the atmospheric furnace were oxidized after a given time and then cooled to obtain the weight gain. The $0.58-\mathrm{Nb}$ and $0.86-\mathrm{Nb}$ steels showed similar measurements after long oxidation times and had higher weight gains than $0-\mathrm{Nb}$ and $0.29-\mathrm{Nb}$ steels. In addition, $0.86-\mathrm{Nb}$ steel gained the highest weight in both tests. 


\subsection{Analysis of Oxide Surface Morphology}

Figure 3 shows the surface morphology after 10 and $150 \mathrm{~h}$ of oxidation. After $10 \mathrm{~h}$ of oxidation, some differences were visible between the steels with and without $\mathrm{Nb}$ addition. In the case of $0-\mathrm{Nb}$ steel, the surface morphology was homogeneous and flat, and the oxides grew along the direction of scratches, as shown in Figure 3a. Figure 3c,e,f shows that on the surface of the steels with $\mathrm{Nb}$ additions of $0.29,0.58$, and 0.86 , some nodules were observed with average sizes of 1,3 , and $6 \mu \mathrm{m}$, respectively. Furthermore, the oxides formed on the nodule-free sites of $\mathrm{Nb}$-added steels were homogeneous and flat, similar to those in $0-\mathrm{Nb}$ steel. The surface morphology of $0-\mathrm{Nb}$ steel after $150 \mathrm{~h}$ oxidation is shown in Figure 3b, in which the oxides remained homogeneous but with a slight increase in the oxide grain size. Figure $3 \mathrm{~d}$ shows that the nodules of $0.29-\mathrm{Nb}$ steel grew after $150 \mathrm{~h}$ of oxidation. Some nodules formed relatively close to the others, and the sites without nodules remained homogeneous. A significant change in the morphology of oxide was found in $0.58-\mathrm{Nb}$ and $0.86-\mathrm{Nb}$ steels. In Figure $3 \mathrm{f}$, a porous, sponge-like oxide can be clearly seen around the nodules of the $0.58-\mathrm{Nb}$ steel and is connected with the other adjacent sponge oxides. In Figure $3 \mathrm{~h}$, the total surface of the $0.86-\mathrm{Nb}$ steel was covered with sponge-like oxide, and partial oxides started to transform into coarse oxides.
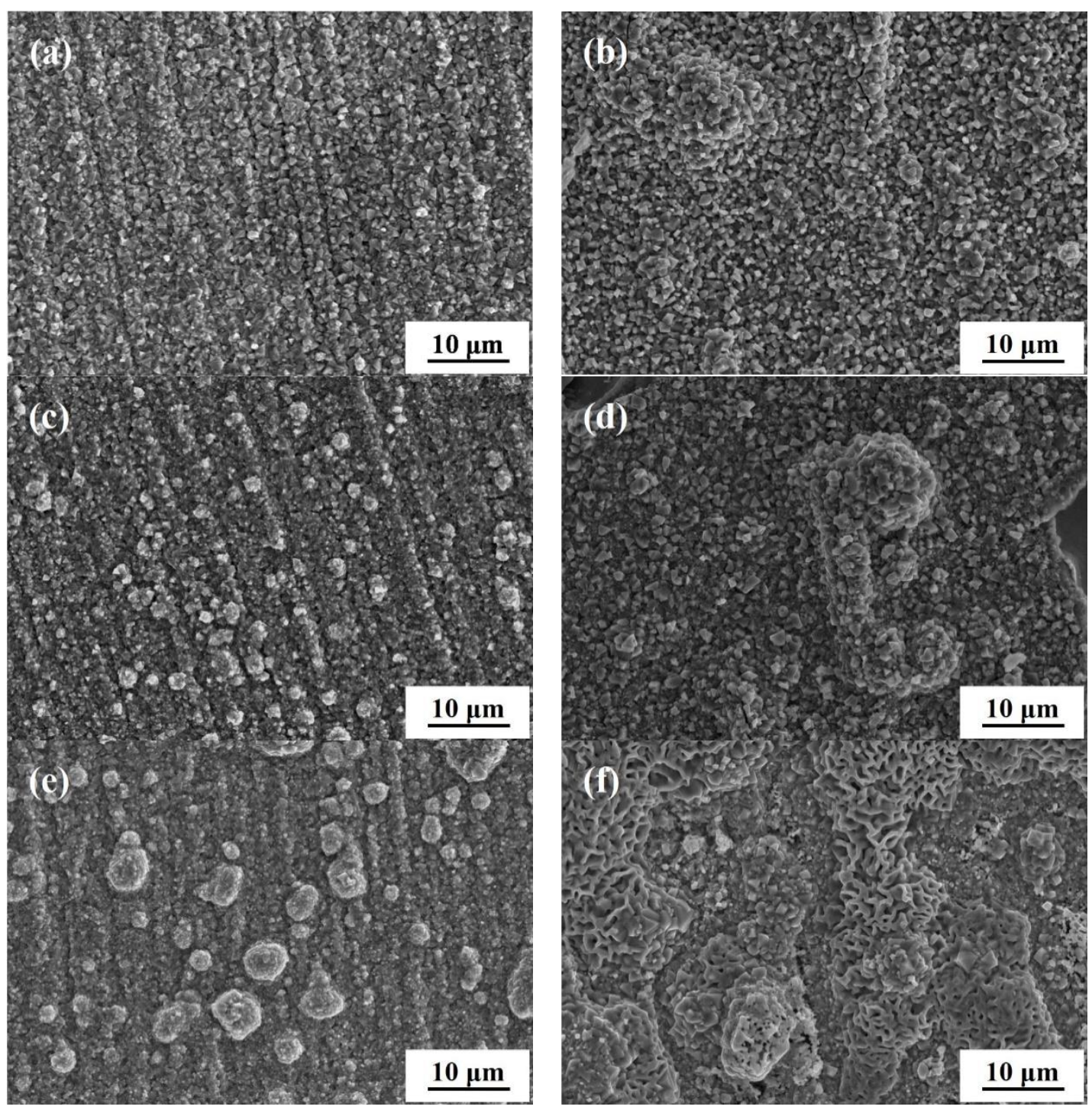

Figure 3. Cont. 

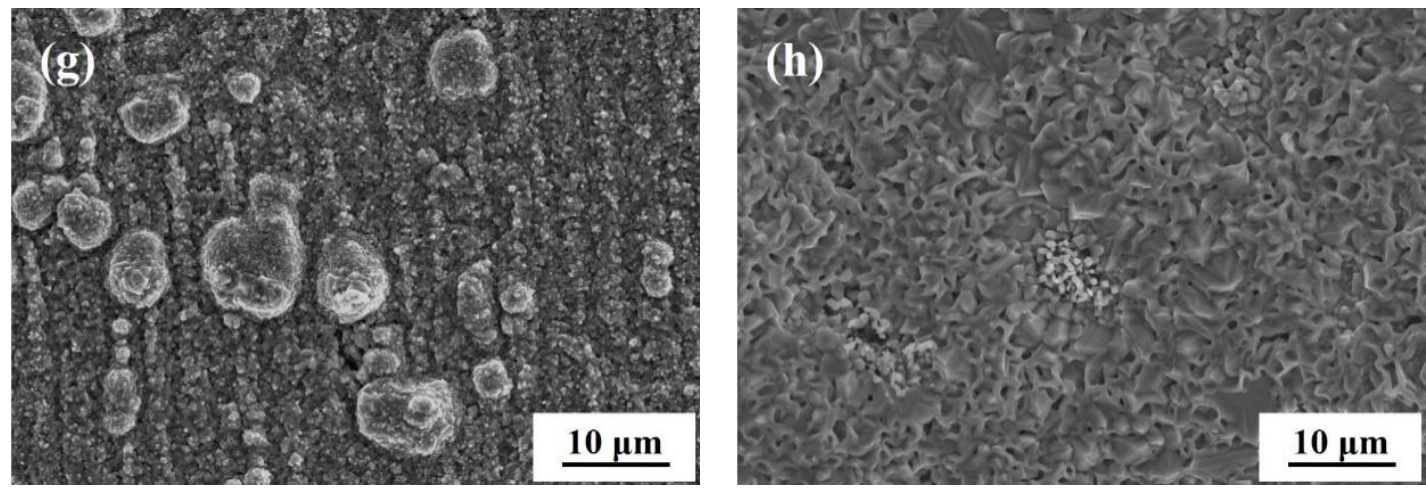

Figure 3. SEM images of the surface morphology of $22 \mathrm{Cr} 25 \mathrm{NiWCoCu}$ stainless steels after oxidation in ambient air (a) with $0 \%$ for $10 \mathrm{~h}$, (b) with $0 \%$ for $150 \mathrm{~h}$, (c) with $0.29 \%$ for $10 \mathrm{~h}$, (d) with $0.29 \%$ for $150 \mathrm{~h}$, (e) with $0.58 \%$ for $10 \mathrm{~h}$, (f) with $0.58 \%$ for $150 \mathrm{~h}$, (g) with $0.86 \%$ for $10 \mathrm{~h}$, and (h) with $0.86 \%$ for $150 \mathrm{~h}$.

Table 4 shows the volume fractions of $\mathrm{Cr}_{2} \mathrm{O}_{3}$, spinel $(\mathrm{Cr}, \mathrm{Mn}, \mathrm{Fe})_{3} \mathrm{O}_{4}$, and $\mathrm{Fe}_{2} \mathrm{O}_{3}$ phases calculated using the TOPAS software. The oxides of $0-\mathrm{Nb}$ steel were composed of $\sim 65-74 \% \mathrm{Cr}_{2} \mathrm{O}_{3}$ and $\sim 21-32 \%$ $\mathrm{M}_{3} \mathrm{O}_{4}$, but Fe oxide was not detected. The oxides of $0.29-\mathrm{Nb}$ steel had no $\mathrm{Fe}_{2} \mathrm{O}_{3}$, but the volume fraction of $\mathrm{Cr}_{2} \mathrm{O}_{3}$ increased to $\sim 76-87 \%$ and that of $\mathrm{M}_{3} \mathrm{O}_{4}$ decreased to $\sim 8-20 \%$. The oxides of $0.58-\mathrm{Nb}$ steel consisted of $\sim 76-92 \% \mathrm{Cr}_{2} \mathrm{O}_{3}$ and $\sim 8-17 \% \mathrm{M}_{3} \mathrm{O}_{4}$ within $100 \mathrm{~h}$, and $\sim 40 \% \mathrm{Fe}_{2} \mathrm{O}_{3}$ was found after $150 \mathrm{~h}$ of oxidation. The $0.86-\mathrm{Nb}$ steel was mostly composed of $\mathrm{Cr}_{2} \mathrm{O}_{3}(\sim 76-93 \%)$ before $75 \mathrm{~h}$ of exposure, but the volume fraction of $\mathrm{Fe}_{2} \mathrm{O}_{3}$ in oxidized specimens increased from $\sim 9$ to $~ 53 \%$ in $100-150 \mathrm{~h}$ of exposure and became the major corrosion product in the outer oxide layer. GI-XRD results revealed that the volume fraction of $\mathrm{Cr}_{2} \mathrm{O}_{3}$ increased with $\mathrm{Nb}$ addition, and $\mathrm{Fe}_{2} \mathrm{O}_{3}$ was formed.

Table 4. Volume fractions of $\mathrm{Cr}_{2} \mathrm{O}_{3}, \mathrm{M}_{3} \mathrm{O}_{4}, \mathrm{Fe}_{2} \mathrm{O}_{3}$, and $\gamma$ phases in 22Cr25NiWCoCu stainless steels with $0-0.86 \% \mathrm{Nb}$ after oxidation in ambient air at $900{ }^{\circ} \mathrm{C}$ for an annealing time of $10-150 \mathrm{~h}$ obtained from grazing incidence $X$-ray using software TOPAS.

\begin{tabular}{|c|c|c|c|c|c|}
\hline Specimen. & Time (h) & $\mathrm{Cr}_{2} \mathrm{O}_{3}(\%)$ & $\mathrm{M}_{3} \mathrm{O}_{4}(\%)$ & $\mathrm{Fe}_{2} \mathrm{O}_{3}(\%)$ & $\gamma(\%)$ \\
\hline \multirow{6}{*}{$0-\mathrm{Nb}$} & 10 & 72.1 & 20.6 & 0 & 7.3 \\
\hline & 25 & 64.5 & 26.9 & 0 & 8.6 \\
\hline & 50 & 66.4 & 32.0 & 0.1 & 1.5 \\
\hline & 75 & 71.8 & 26.9 & 0.4 & 0.9 \\
\hline & 100 & 67.8 & 28.0 & 0 & 4.2 \\
\hline & 150 & 73.5 & 23.5 & 2.7 & 0.3 \\
\hline \multirow{6}{*}{$0.29-\mathrm{Nb}$} & 10 & 76.8 & 9.8 & 0 & 13.4 \\
\hline & 25 & 76.0 & 10.1 & 0 & 13.9 \\
\hline & 50 & 76.3 & 19.5 & 3.4 & 0.8 \\
\hline & 75 & 87.4 & 7.5 & 0 & 5.1 \\
\hline & 100 & 86.7 & 9.6 & 2.7 & 1.0 \\
\hline & 150 & 80.5 & 12.3 & 0.9 & 6.3 \\
\hline \multirow{6}{*}{$0.58-\mathrm{Nb}$} & 10 & 75.8 & 8.2 & 0 & 16.0 \\
\hline & 25 & 79.9 & 12.7 & 2.8 & 4.6 \\
\hline & 50 & 82.6 & 17.3 & 0 & 0.1 \\
\hline & 75 & 91.9 & 5.8 & 1.6 & 0.7 \\
\hline & 100 & 90.3 & 6.5 & 2.4 & 0.8 \\
\hline & 150 & 40.1 & 16.7 & 38.1 & 5.1 \\
\hline \multirow{6}{*}{$0.86-\mathrm{Nb}$} & 10 & 75.7 & 9.1 & 1.7 & 13.5 \\
\hline & 25 & 86.5 & 11.0 & 2.0 & 0.5 \\
\hline & 50 & 83.6 & 14.4 & 0 & 2.0 \\
\hline & 75 & 93.1 & 6.0 & 0.7 & 0.2 \\
\hline & 100 & 81.7 & 8.2 & 9.4 & 0.7 \\
\hline & 150 & 26.5 & 12.1 & 53.1 & 8.3 \\
\hline
\end{tabular}




\subsection{Analysis of Oxide Layers at Cross-Section}

The microstructures of the oxide layer at cross-section after 10-150 h are shown in Figure 4. A significant difference in the microstructure was found between the steels with and without $\mathrm{Nb}$ addition. Nodules were observed in steels with $\mathrm{Nb}$ addition, as shown in Figure $4 \mathrm{~b}-\mathrm{d}$, but not in $0-\mathrm{Nb}$ steel as shown in Figure 4a. Furthermore, oxide layers with nodules were thicker than those without nodules, and precipitates were found around the nodules. After $150 \mathrm{~h}, 0-\mathrm{Nb}$ steel had a $3 \mu \mathrm{m}$-thick oxide layer without nodules. The formation of nodules was observed in $0.29-\mathrm{Nb}$ steel, and the 10 $\mu \mathrm{m}$-thick oxide layer of the nodule became loose. The oxide layers of $0.58-\mathrm{Nb}$ and $0.86-\mathrm{Nb}$ steels had thicknesses of $\sim 12$ and $\sim 15 \mu \mathrm{m}$, respectively. The $0.86-\mathrm{Nb}$ steel had many porous structures, whereas the $0.58-\mathrm{Nb}$ steel had fewer.

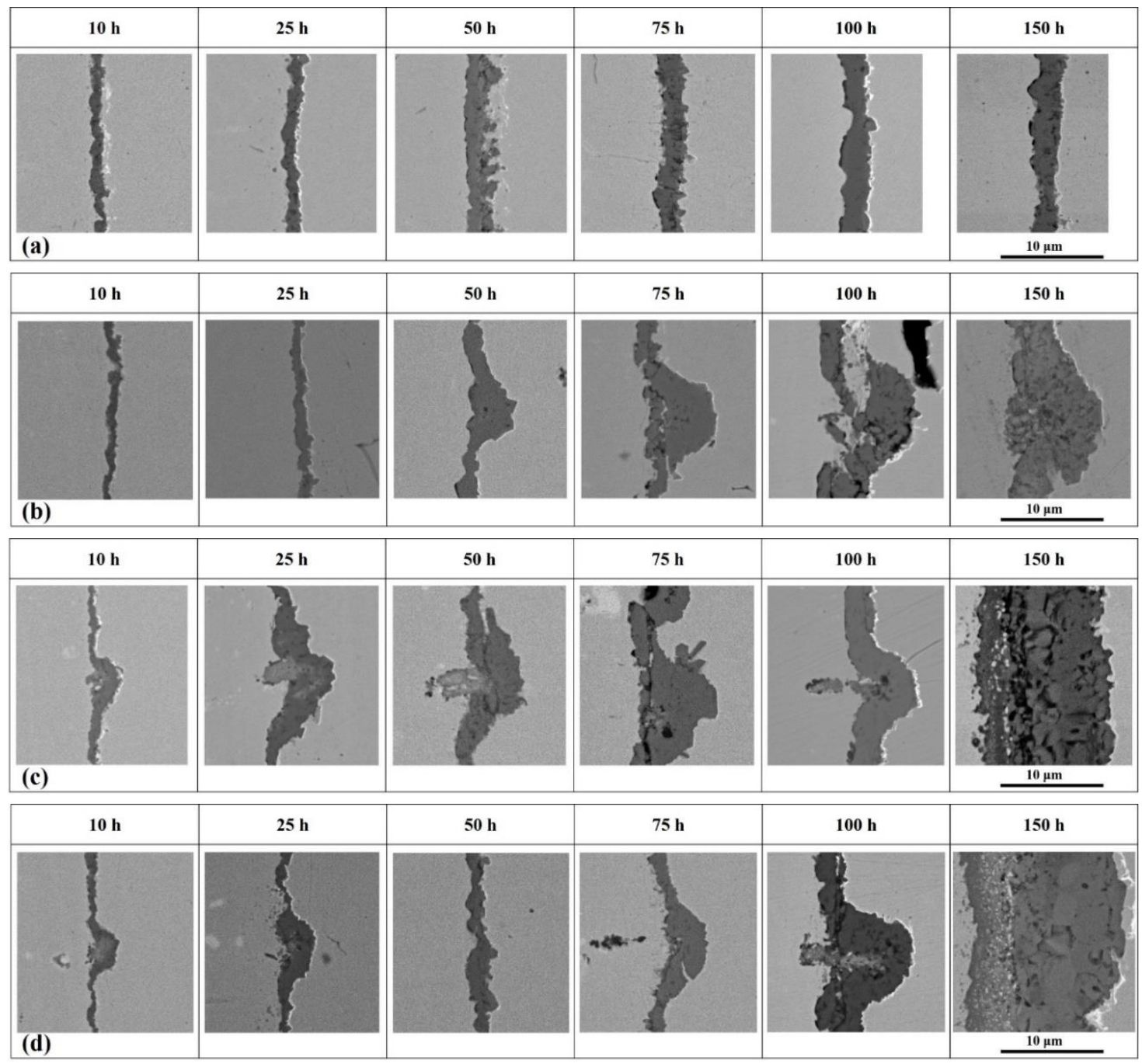

Figure 4. Optical micrograph of the oxide layer as a function of annealing time in $22 \mathrm{Cr} 25 \mathrm{NiWCoCu}$ stainless steels with $\mathrm{Nb}$ contents of (a) 0 , (b) 0.29 , (c) 0.58 , and (d) 0.86 wt.\%.

Figure 5a, Figure 6a, Figure 7a, Figure 8a show the images of the oxide layers from the forward-scattered electron detector (FSD), where the white frame represents the scanning area for the EBSD analysis, and the black solid lines are the scanned regions of the EDS line scan. Figure 5b-e, Figure $6 \mathrm{~b}-\mathrm{e}$, Figure $7 \mathrm{~b}-\mathrm{e}$, Figure $8 \mathrm{~b}-\mathrm{e}$ show the results of EBSD maps and EDS line scans at the cross section of the oxide layer after $150 \mathrm{~h}$, where the white dotted lines represent the interface between the oxide layer and the electroplating Ni layer. The findings of EBSD map in Figure 5e show that the major oxide layer of $0-\mathrm{Nb}$ steel was composed of $\mathrm{Cr}_{2} \mathrm{O}_{3}$ and spinel $(\mathrm{Cr}, \mathrm{Mn})_{3} \mathrm{O}_{4}$. Some parts of the EBSD may 
not emit a signal because of the shadow effect of the pore formation and the uneven surface at the interface. The line scan result shows that the oxide layer had $\mathrm{Mn}, \mathrm{Cr}$, and $\mathrm{O}$ but no Fe oxide, as shown in Figure 5f. Furthermore, the oxides of $\mathrm{Cr}_{2} \mathrm{O}_{3}$ and spinel $(\mathrm{Cr}, \mathrm{Mn})_{3} \mathrm{O}_{4}$ were columnar and did not show a preferred orientation, as displayed in Figure $5 \mathrm{c}, \mathrm{d}$.
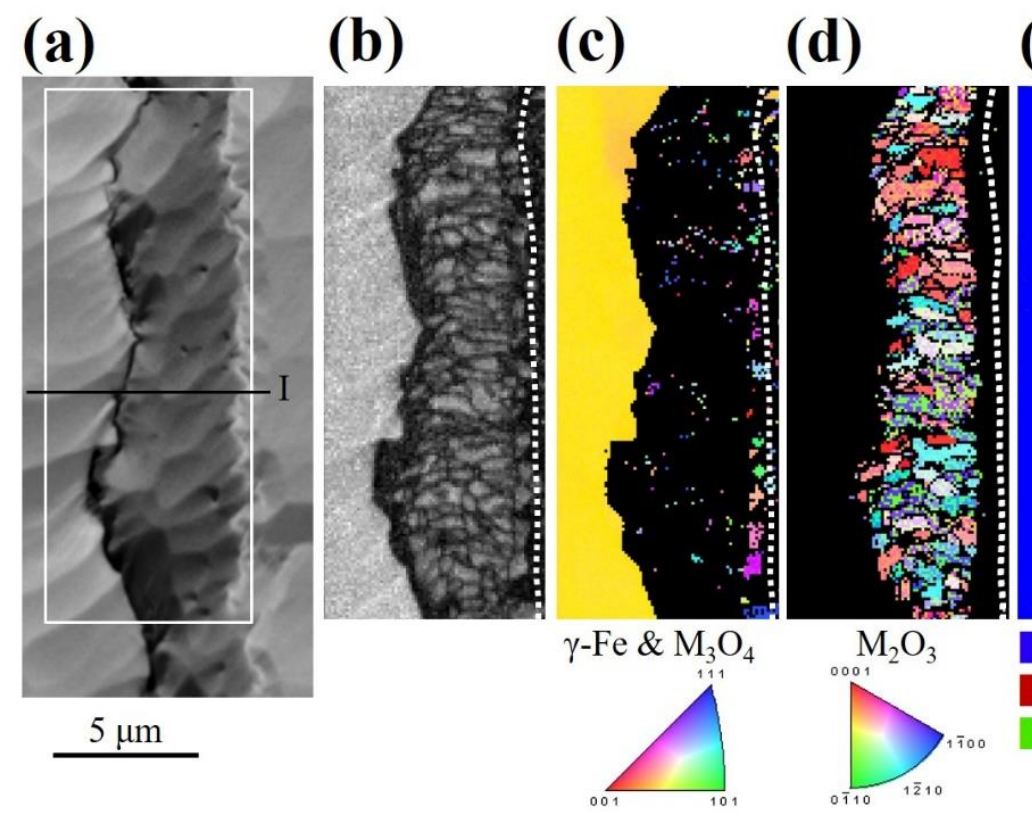

(e)
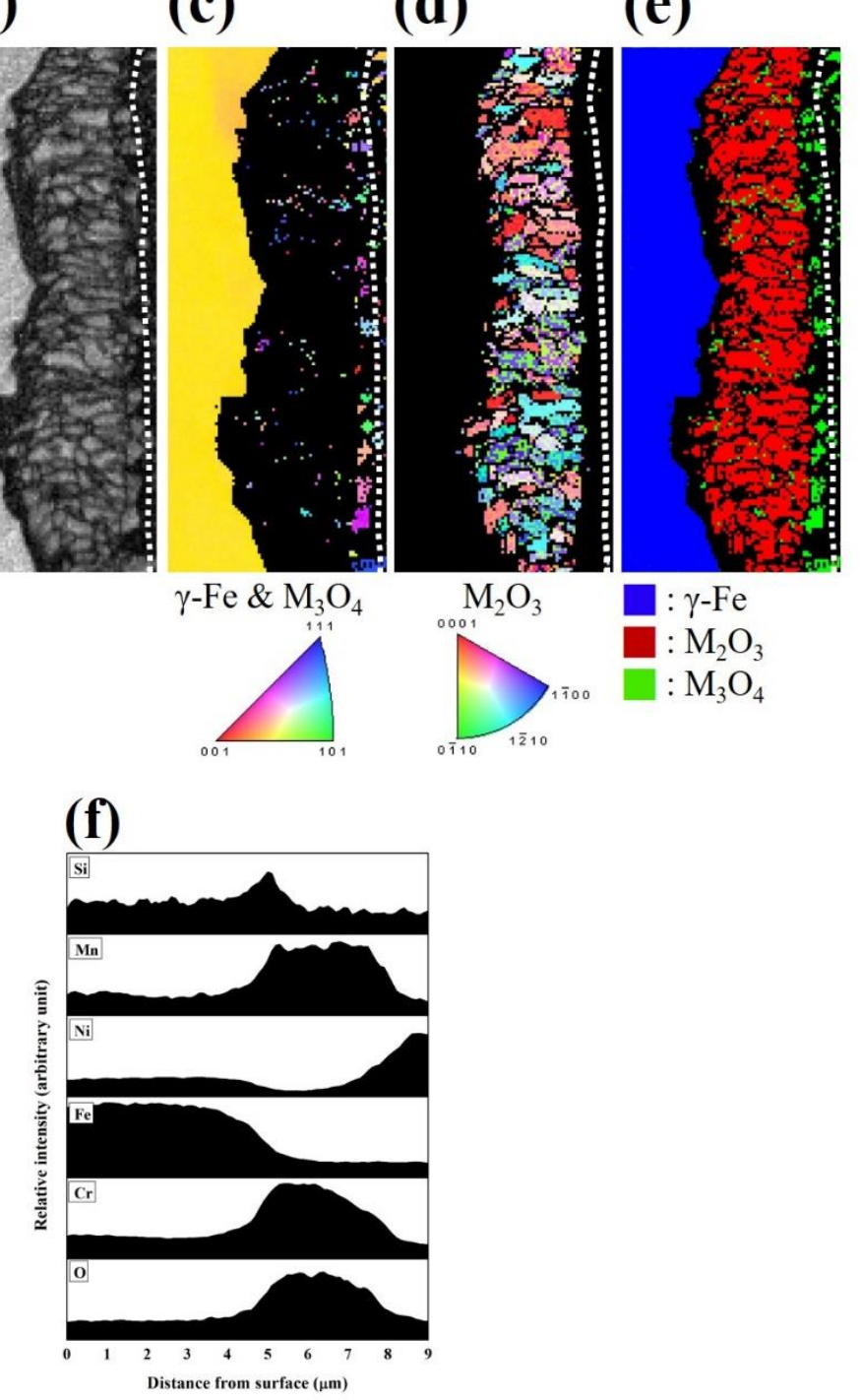

Figure 5. (a) Forward-scattered electron detector (FSD) image, (b) image quality map, (c) inverse pole figure map for $\gamma$ and $\mathrm{M}_{3} \mathrm{O}_{4}$ phases, (d) inverse pole figure map for $\mathrm{M}_{2} \mathrm{O}_{3}$ phase, and (e) phase map of the oxide layers in $22 \mathrm{Cr} 25 \mathrm{NiWCoCu}$ stainless steel with $0 \% \mathrm{Nb}$ after oxidation in ambient air for $150 \mathrm{~h}$.

(f) EDS line scan of $\mathrm{Si}, \mathrm{Mn}, \mathrm{Ni}, \mathrm{Fe}, \mathrm{Cr}$, and $\mathrm{O}$ along line I in (a).

The phase map in Figure 6e and the EDS line scans in Figure 6f,g show that the major oxide of 0.29- $\mathrm{Nb}$ steel was $\mathrm{Cr}_{2} \mathrm{O}_{3}$, and spinel was found at the steel's outer layer. Results of EDS line scan also show an increase in Fe and a decrease in $\mathrm{Cr}$ at the bottom of the nodule in Figure $6 \mathrm{f}$. Some of the oxide grains were almost columnar, but some were almost equiaxed where the oxides $\mathrm{Cr}_{2} \mathrm{O}_{3}$ and spinel exhibited small grain sizes and random orientations, as shown in Figure 6c,d. 
(a)

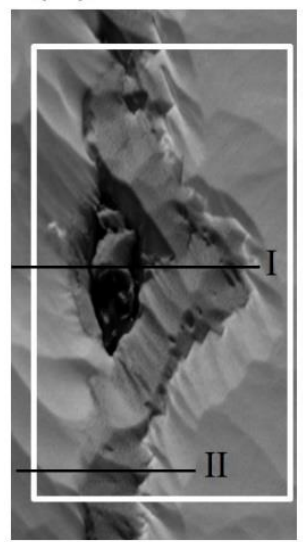

$5 \mu \mathrm{m}$ (b)

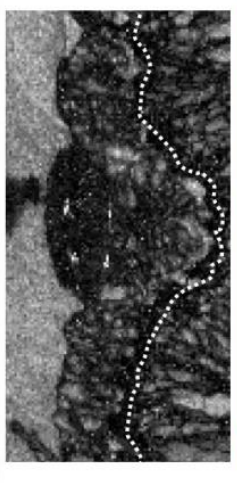

$\gamma$-Fe \& $\mathrm{M}_{3} \mathrm{O}_{4}$

(d)

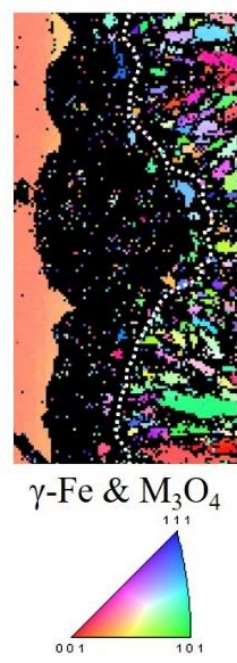

(e)

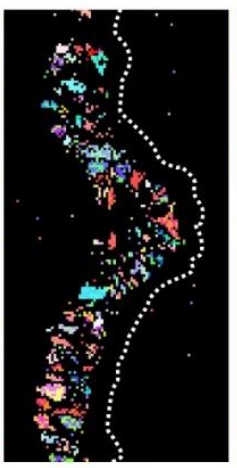

$\mathrm{M}_{2} \mathrm{O}_{3}$

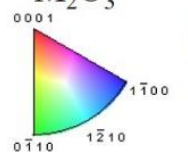

: $\gamma$-Fe

$: \mathrm{M}_{2} \mathrm{O}_{3}$

: $\mathrm{M}_{3} \mathrm{O}_{4}$
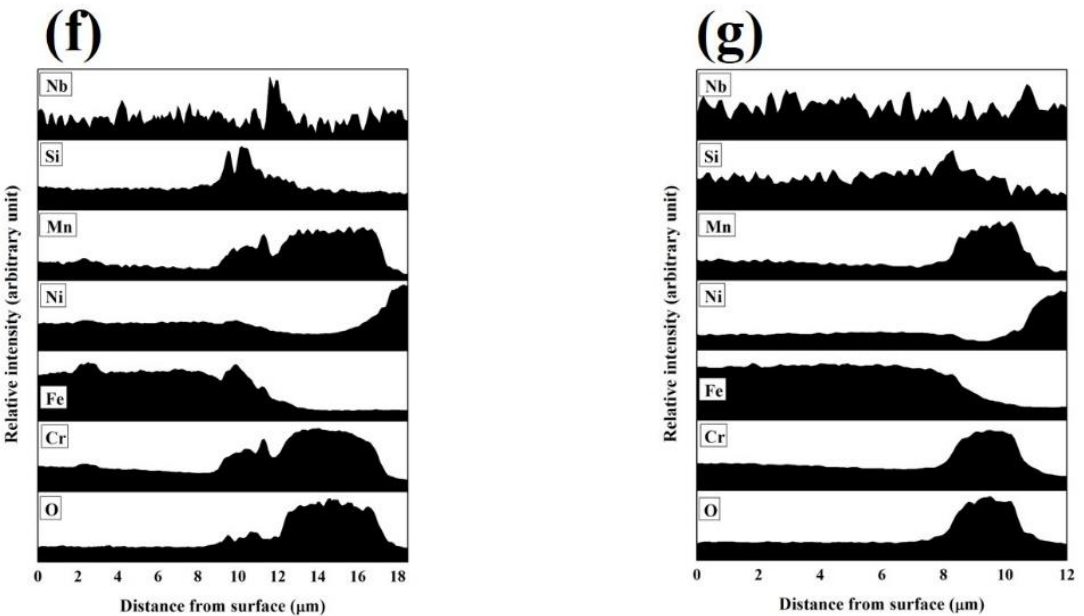

Figure 6. (a) FSD image, (b) image quality map, (c) inverse pole figure map for $\gamma$ and $\mathrm{M}_{3} \mathrm{O}_{4}$ phases, (d) inverse pole figure map for $\mathrm{M}_{2} \mathrm{O}_{3}$ phase, and (e) phase map of the oxide layers in $22 \mathrm{Cr} 25 \mathrm{NiWCoCu}$ stainless steel with $0.29 \% \mathrm{Nb}$ after oxidation in ambient air for $150 \mathrm{~h}$. (f) EDS line scan of $\mathrm{Si}, \mathrm{Mn}, \mathrm{Ni}, \mathrm{Fe}$, $\mathrm{Cr}$, and $\mathrm{O}$ along lines $\mathrm{I}$ and II in (a) and (g) EDS line scan of $\mathrm{Si}, \mathrm{Mn}, \mathrm{Ni}, \mathrm{Fe}, \mathrm{Cr}$, and $\mathrm{O}$ along line II in (a).

In the case of $0.58-\mathrm{Nb}$ steel, the phase map in Figure 7e shows that some large-sized spinel formed inside the nodules. In addition, the EDS line scan in Figure $7 \mathrm{f}$ shows that Fe signals were detected in the center and top surface of the nodule. A low content of $\mathrm{Cr}$ was also detected at the center of the nodule. These observations revealed that the high consumption of $\mathrm{Cr}$ led to $\mathrm{Cr}$ depletion around the $\mathrm{Nb}$ precipitates and, subsequently, led to iron oxide formation. Fine equiaxed grains of $\mathrm{Cr}_{2} \mathrm{O}_{3}$ and spinel at the oxide layer were observed, and no preferred orientation was found in the oxide grains, as shown in Figure 7c,d. 

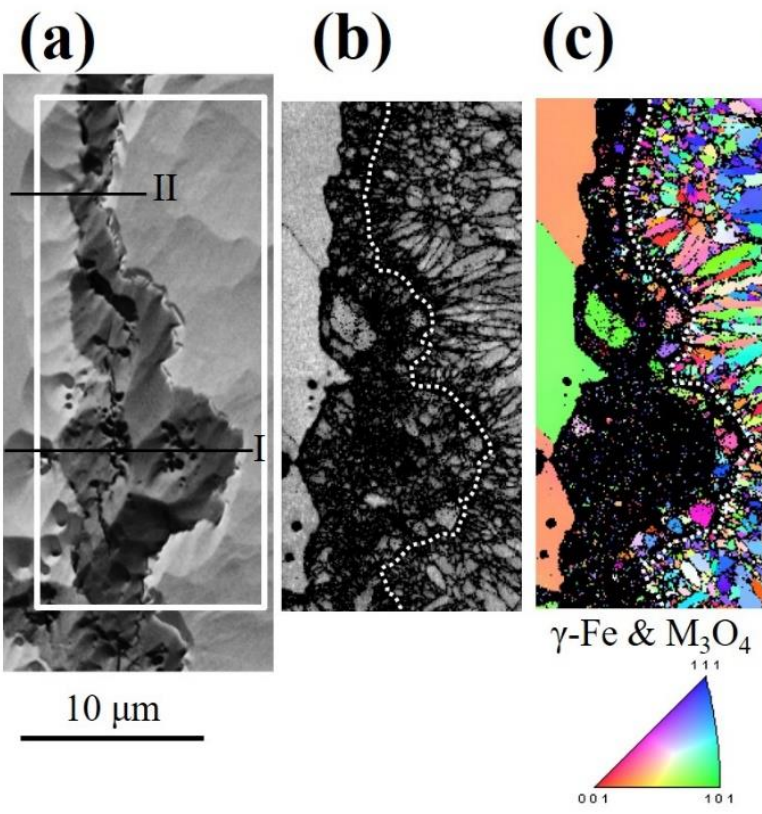

(d)

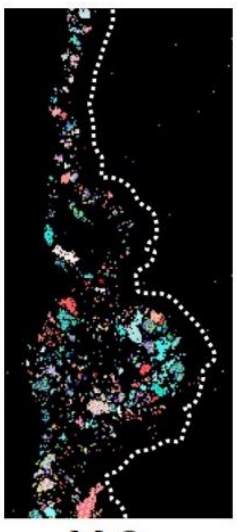

$\underset{0001}{\mathrm{M}_{2} \mathrm{O}_{3}}$

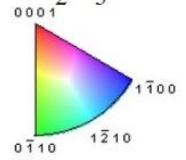

$\square: \gamma-\mathrm{Fe}$

: $\mathrm{M}_{2} \mathrm{O}_{3}$

$: \mathrm{M}_{3} \mathrm{O}_{4}$
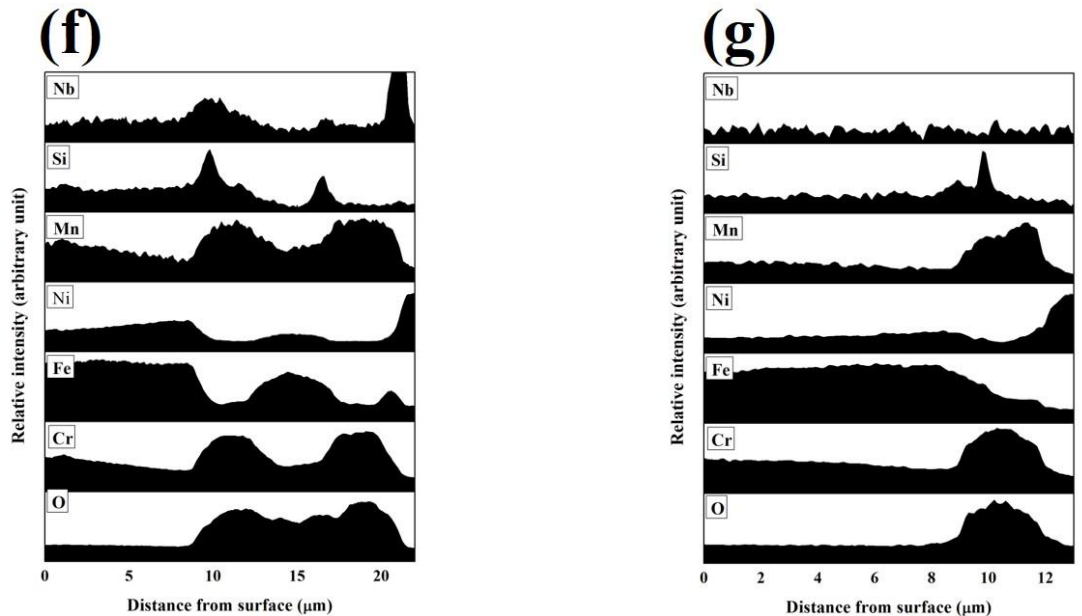

Figure 7. (a) FSD image, (b) image quality map, (c) inverse pole figure map for $\gamma$ and $\mathrm{M}_{3} \mathrm{O}_{4}$ phases, (d) inverse pole figure map for $\mathrm{M}_{2} \mathrm{O}_{3}$ phase, and (e) phase map of the oxide layers in $22 \mathrm{Cr} 25 \mathrm{NiWCoCu}$ stainless steel with $0.58 \% \mathrm{Nb}$ after oxidation in ambient air for $150 \mathrm{~h}$. (f) EDS line scan of $\mathrm{Si}, \mathrm{Mn}, \mathrm{Ni}, \mathrm{Fe}$, $\mathrm{Cr}$, and $\mathrm{O}$ along lines I and II in (a) and (g) EDS line scan of $\mathrm{Si}, \mathrm{Mn}, \mathrm{Ni}, \mathrm{Fe}, \mathrm{Cr}$, and $\mathrm{O}$ along line II in (a).

In $0.86-\mathrm{Nb}$ steel, the major oxides in the outer layer were hematite and magnetite, the inner layer contained $(\mathrm{Cr}, \mathrm{Fe}, \mathrm{Mn})_{3} \mathrm{O}_{4}$, and a transition layer had $\mathrm{Cr}_{2} \mathrm{O}_{3}$ between both layers, as displayed in Figure $8 \mathrm{e}-\mathrm{g}$. The oxide layer of $0.86-\mathrm{Nb}$ after $150 \mathrm{~h}$ exposure did not have any nodules and was relatively thicker than those of the other three materials. Inverse pole figure maps show the random orientation of the oxide for the $\mathrm{M}_{3} \mathrm{O}_{4}$ and the $\mathrm{Cr}_{2} \mathrm{O}_{3}$ layers in Figure 8c,d. 
(a)

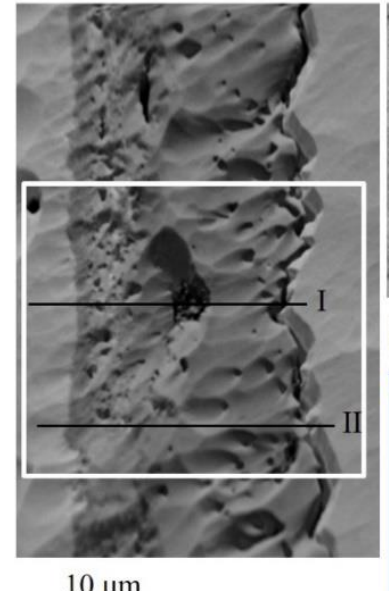

$10 \mu \mathrm{m}$ (b)

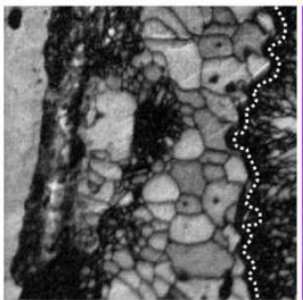

(e)

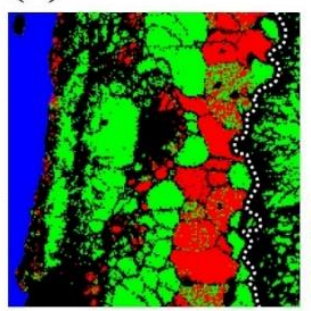

(c)

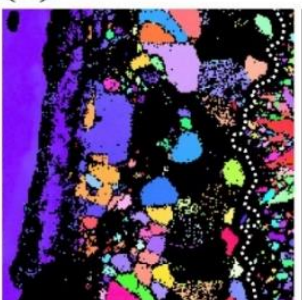

$\gamma$-Fe \& $\mathrm{M}_{3} \mathrm{O}_{4}$

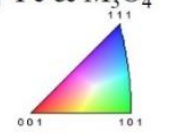

(d)

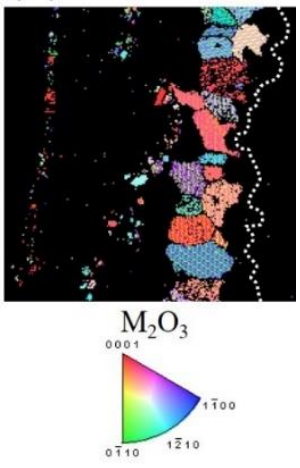

$\gamma-\mathrm{Fe}$

$\mathrm{M}_{2} \mathrm{O}_{3}$

$: \mathrm{M}_{3} \mathrm{O}_{4}$
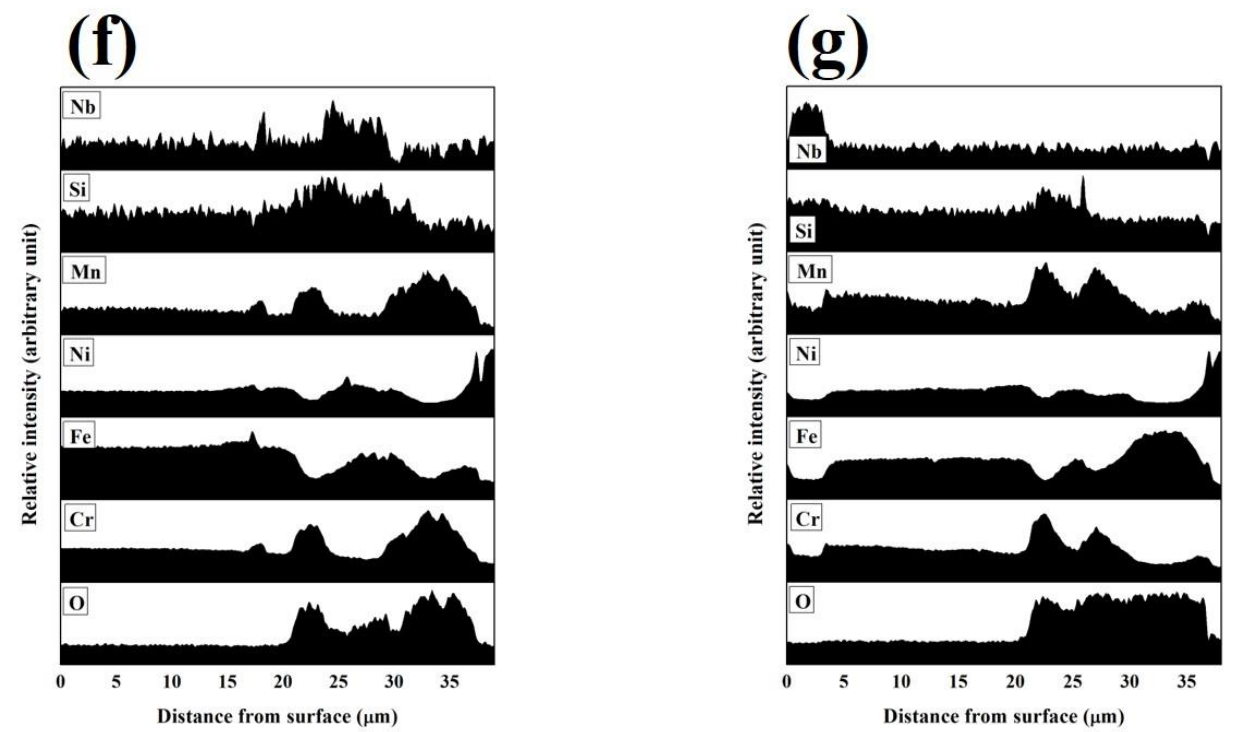

Figure 8. (a) FSD image, (b) image quality map, (c) inverse pole figure map for $\gamma$ and $\mathrm{M}_{3} \mathrm{O}_{4}$ phases, (d) inverse pole figure map for $\mathrm{M}_{2} \mathrm{O}_{3}$ phase, and (e) phase map of the oxide layers in $22 \mathrm{Cr} 25 \mathrm{NiWCoCu}$ stainless steel with $0.86 \% \mathrm{Nb}$ after oxidation in ambient air for $150 \mathrm{~h}$. (f) EDS line scan of $\mathrm{Si}, \mathrm{Mn}, \mathrm{Ni}, \mathrm{Fe}$, $\mathrm{Cr}$, and $\mathrm{O}$ along lines I and II in (a) and (g) EDS line scan of $\mathrm{Si}, \mathrm{Mn}, \mathrm{Ni}, \mathrm{Fe}, \mathrm{Cr}$, and $\mathrm{O}$ along line II in (a).

\subsection{Effect of $\mathrm{Nb}$ Addition on Oxidation Behavior}

An increase in $\mathrm{Nb}$ addition caused a decrease in the average grain size, as shown in Figure 1. According to TGA curves shown in Figure 2a, the steels with $\mathrm{Nb}$ additions had higher oxidation rates before $50 \mathrm{~h}$ than those without $\mathrm{Nb}$ addition. The reduction of grain size by $\mathrm{Nb}$ addition increased the density of the grain boundary, thus offering many outward diffusion paths for $\mathrm{Cr}$ and, consequently, enhancing the oxidation rate.

In 1957, Hart [25] proposed an effective volumetric diffusion that was associated with matrix and dislocation. Following Hart's concept, Smeltzer [26] proposed the effective diffusion constant as follows:

$$
D_{\text {eff }}=(1-f) * D_{L}+f * D_{G B},
$$

where $D_{\text {eff }}$ is the effective diffusion, $f$ is the parameter associated with grain boundaries and grain size, $D_{L}$ is the lattice diffusivity, and $D_{G B}$ is the grain boundary diffusivity. Here, $f$ is equal to $2 \delta / \mathrm{d}$, in which 
$\delta$ is the grain boundary width at approximately $0.5 \mathrm{~nm}$, and $\mathrm{d}$ is the average grain size. Equation (2) can be rewritten as:

$$
D_{e f f}=D_{L}+f *\left(D_{G B}-D_{L}\right) .
$$

According to self-diffusion in face-centered cubic metals [27], $D_{G B}$ is $\sim 6$ orders of magnitude higher than $D_{L}$ at an oxidation temperature of $900^{\circ} \mathrm{C}$. Hence, Equation (3) can be simplified as:

$$
D_{e f f}=2 \delta * D_{G B} / d
$$

With the help of Equation (4), the $D_{\text {eff }}$ for all steels is calculated as follows:

$$
D_{e f f}^{N b-f r e e}: D_{e f f}^{0.29-N b}: D_{e f f}^{0.58-N b}: D_{e f f}^{0.86-N b}=1: 3: 3.8: 4.8 .
$$

Apart from refining the grain size, $\mathrm{Nb}$ addition increased the formation of $\mathrm{Cr}_{2} \mathrm{O}_{3}$ and reduced that of $\mathrm{M}_{3} \mathrm{O}_{4}$, as shown in Table 4. Here, the formation of $\mathrm{Cr}_{2} \mathrm{O}_{3}$ and $\mathrm{M}_{3} \mathrm{O}_{4}$ lies in the inner and the outer oxide layers, as shown in Figures 5-8. Compared with the diffusion coefficients of $\mathrm{Cr}$ and $\mathrm{Mn}$ [28], that of $\mathrm{Mn}$ was 2 orders of magnitude higher than that of $\mathrm{Cr}$. Therefore, spinel $(\mathrm{Cr}, \mathrm{Mn})_{3} \mathrm{O}_{4}$ formed at the outer oxide layer in 0-Nb steel. GI-XRD results show that the formation of $\mathrm{Cr}_{2} \mathrm{O}_{3}$ increased with $\mathrm{Nb}$ addition before $100 \mathrm{~h} . \mathrm{Cr}_{2} \mathrm{O}_{3}$ was the major oxide in $\mathrm{Nb}$-containing and $0-\mathrm{Nb}$ steels. The reduction of grain size has a beneficial effect on the formation of $\mathrm{Cr}_{2} \mathrm{O}_{3}$ [14-19].

\subsection{Effect of Precipitates on the Oxidation Behavior}

According to the above-mentioned results in Section 3.5, 0.86- $\mathrm{Nb}$ steel should have a higher oxidation rate than $0.58-\mathrm{Nb}$ steel; however, the latter obtained the highest oxidation rate. This finding indicates that the grain size did not affect the oxidation rate. According to a previous study [13], the volume fractions of $\mathrm{Nb}(\mathrm{C}, \mathrm{N})$ precipitates for $0-\mathrm{Nb}, 0.29-\mathrm{Nb}, 0.58-\mathrm{Nb}$, and $0.86-\mathrm{Nb}$ were $0,3.1,5.2$, and $3.5 \mathrm{wt} . \%$, respectively.

According to the microstructure of the surface (Figure 2) and cross-sectional analysis (Figures 4-8), nodules were only found in the steels with $\mathrm{Nb}$ addition. Small-sized nodules disappeared, and large-sized ones had grown with prolonged oxidation. Porous, sponge-like oxides initially formed at the nodules and then immediately transformed into large-sized oxides. From the cross-sectional microstructure of the oxide layer, a $\mathrm{Nb}(\mathrm{C}, \mathrm{N})$ precipitate was always found embedded in the nodule, indicating that the formation of nodules was induced by these $\mathrm{Nb}(\mathrm{C}, \mathrm{N})$ precipitates. These phenomena may be attributed to the high $\mathrm{Cr}$ consumption rate at the interface of precipitates and substrate. Therefore, the effect of precipitates contributes to the oxidation rate. This finding explains the higher oxidation rate of $0.58-\mathrm{Nb}$ steel at the initial stage.

At the initial stage, a protective $\mathrm{Cr}_{2} \mathrm{O}_{3}$ layer existed on the surface, and the $\mathrm{Cr}_{2} \mathrm{O}_{3}$ oxide was the major component of oxide layer before $100 \mathrm{~h}$, as shown in Table 4. Considering the effects of grain size and precipitates, $0.86-\mathrm{Nb}$ steel should have the highest weight gain per unit area. After a long oxidation time, the $0.86-\mathrm{Nb}$ steel had the highest weight gain per unit area. After $150 \mathrm{~h}$, the $\mathrm{Fe}_{2} \mathrm{O}_{3}$ oxide became the major component of $0.58-\mathrm{Nb}$ and $0.86-\mathrm{Nb}$ steels. The high consumption of $\mathrm{Cr}$ for $0.86-\mathrm{Nb}$ steel led to $\mathrm{Cr}$ depletion around $\mathrm{Nb}$ precipitates, as shown in Figure 7f. Furthermore, the $\mathrm{Nb}(\mathrm{C}, \mathrm{N})$ at the center of the nodules led to the breakdown of the oxide layer. Thus, $\mathrm{Cr}$ cannot be continuously supplemented from the matrix due to $\mathrm{Cr}$ depletion, that is, when the concentration of $\mathrm{Cr}$ is lower than $\sim 15 \mathrm{wt}$.\% [14]. Fe may then start to form into a porous oxide layer of $\mathrm{Fe}_{2} \mathrm{O}_{3}$, resulting in the increased oxidation rate compared with that of the compact oxide layer of $\mathrm{Cr}_{2} \mathrm{O}_{3}$. The formation of nodules can be induced by the concentration of the protective oxide former [29-32], inhomogeneity of the chemical composition of alloy [33], surface roughness [34], breakdown of the protective oxide layer [35-37], and grain boundaries [38,39]. Allen et al. reported that the mounds (nodules) result from the phase transformation of $\mathrm{Nb}(\mathrm{C}, \mathrm{N})$ during high-temperature oxidation [11]. In Tayler's study, $\mathrm{Nb}(\mathrm{C}, \mathrm{N})$ was found at the center of these mounds during phase transformation [12]. 
According to the above discussions, a schematic diagram for the formation of the oxide layer in terms of $\mathrm{Nb}(\mathrm{C}, \mathrm{N})$ precipitates is summarized in Figure 9 to understand the growth evolution of the oxide layer. At Stage I, a $\mathrm{Cr}_{2} \mathrm{O}_{3}$ oxide layer formed instantly on the specimen surface.

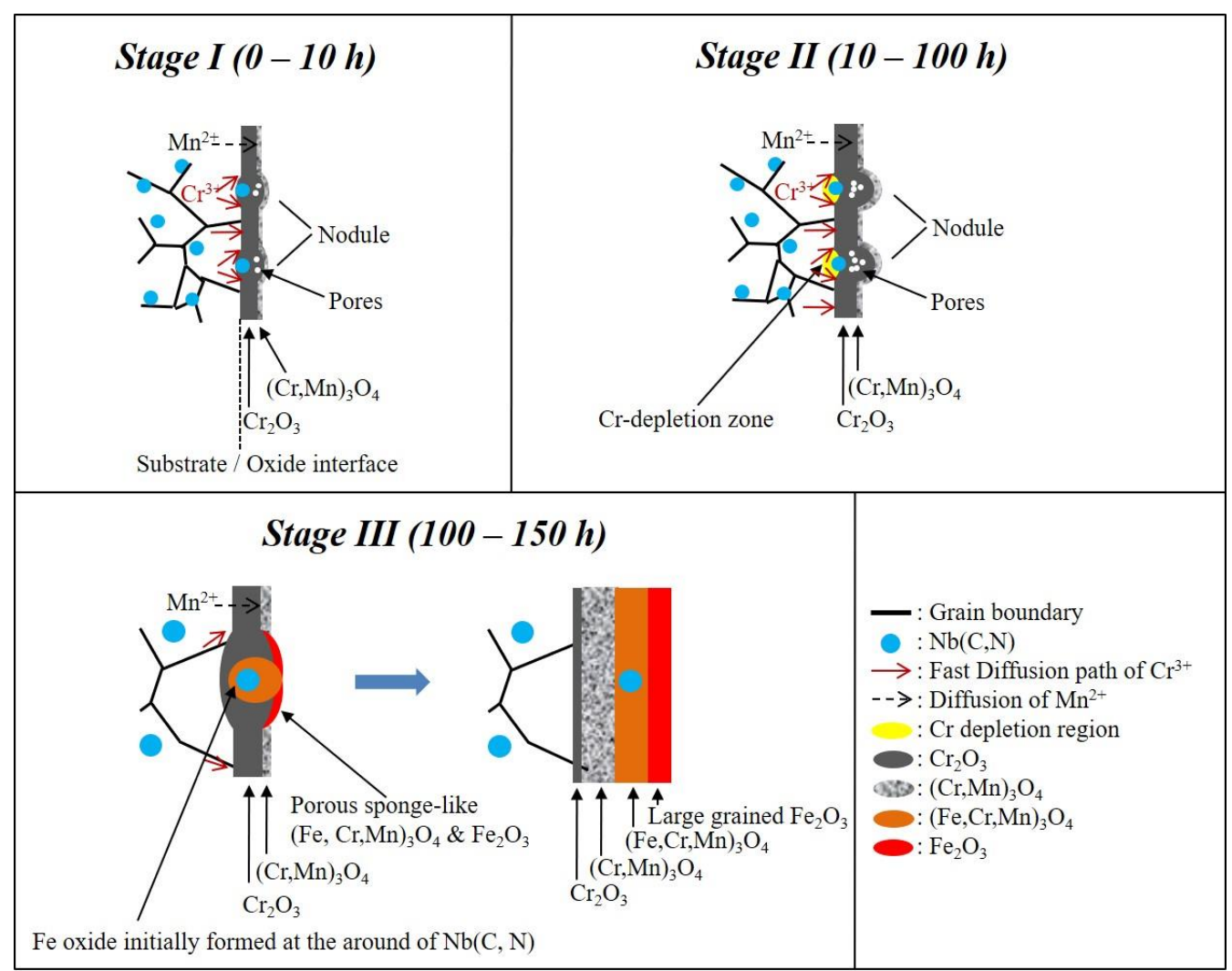

Figure 9. Schematic diagram of the growth stages of the oxide layer around $\mathrm{Nb}(\mathrm{C}, \mathrm{N})$.

Oxide clusters were observed at the region with $\mathrm{Nb}(\mathrm{C}, \mathrm{N})$ particles, which were imbedded in nodules. The oxide layer grew faster in the region with nodules than in the area without nodules. At Stage II, the region with nodules grew at a high $\mathrm{Cr}$ consumption rate, resulting in $\mathrm{Cr}$ depletion. Consequently, Fe oxides were initially formed at $\mathrm{Cr}$-depleted zones around precipitates. Finally, at Stage III, a thick oxide layer consisting of $\mathrm{Fe}_{2} \mathrm{O}_{3}$ at the outer layer and $(\mathrm{Cr}, \mathrm{Fe}, \mathrm{Mn})_{3} \mathrm{O}_{4}$ at the inner layer was formed.

\section{Conclusions}

An increase in $\mathrm{Nb}$ content refined the grain size from 426 to $90 \mu \mathrm{m}$, promoted the formation of $\mathrm{Cr}_{2} \mathrm{O}_{3}$, and avoided the formation of $\mathrm{M}_{3} \mathrm{O}_{4}$. In addition, the volume fraction of $\mathrm{Nb}(\mathrm{C}, \mathrm{N})$ precipitates increased from $0 \%$ to $5.2 \%$ when the $\mathrm{Nb}$ content increased from $0-0.58 \mathrm{wt} . \%$, but it decreased to $3.5 \%$ when the $\mathrm{Nb}$ content was $0.86 \mathrm{wt} . \%$.

After 0-10 h, a $\mathrm{Cr}_{2} \mathrm{O}_{3}$ oxide layer formed, and oxide- $\mathrm{Nb}(\mathrm{C}, \mathrm{N})$ particle clusters appeared in nodules. After 10-100 h, a high $\mathrm{Cr}$ consumption rate was observed in the nodule-forming regions, resulting in $\mathrm{Cr}$ depletion. Consequently, Fe oxides were generated at the $\mathrm{Cr}$-depleted zones with $\mathrm{Nb}$ $(\mathrm{C}, \mathrm{N})$ precipitates. Finally, after $100 \mathrm{~h}$, a thick oxide layer composed of an $\mathrm{Fe}_{2} \mathrm{O}_{3}$ outer layer and $(\mathrm{Cr}$, $\mathrm{Fe}, \mathrm{Mn})_{3} \mathrm{O}_{4}$ inner layer was synthesized.

Author Contributions: Conceptualization, S.-Y.H., J.-C.K., D.-Y.L., Y.-T.P.; Data curation, S.-Y.H., J.-C.K.; Formal analysis, S.-Y.H.; Supervision, J.-C.K.; Funding acquisition, J.-C.K.; Investigation, S.-Y.H., J.-C.K.; Methodology, S.-Y.H., J.-C.K., W.-T.T., Y.-T.P.; Project administration, J.-C.K.; Resources, J.-C.K., W.-T.T., D.-Y.L., Y.-T.P., H.-W.C.

Funding: This research received no external funding. 
Acknowledgments: The authors are thankful for the support provided by China Steel Corporation for alloy casting, hot rolling, and heat treatment. The authors also wish to express thanks for the support of TGA test by Dhu's lab in National Tsing Hua University and for supporting the fund in the project under MOST 107-2221-E-006-018 from the Ministry of Science and Technology.

Conflicts of Interest: The authors declare no conflict of interest

\section{References}

1. International Energy Agency. Global Energy \& CO2 Status Report-The latest trends in energy and emissions in 2017. Available online: https://www.iea.org/publications/freepublications/publication/GECO2017.pdf (accessed on 23 March 2018).

2. Aroonwilas, A.; Veawab, A. Integration of $\mathrm{CO}_{2}$ capture unit using single- and blended-amines into supercritical coal-fired power plants: Implications for emission and energy management. Int. J. Greenh. Gas. Control. 2007, 1, 43-150. [CrossRef]

3. Wood, G.C.; Wright, I.G.; Hodgkiess, T.; Whittle, D.P. A Comparison of the Oxidation of Fe-Cr, Ni-Cr and Co-Cr Alloys in Oxygen and Water Vapour. Mater. Corros. 1970, 21, 900-910. [CrossRef]

4. Birks, N.; Meier, G.H.; Pettit, F.S. Introduction to the high temperature oxidation of metals, 2nd ed.; Cambridge University Press: Cambridge, UK, 2006; ISBN 978-0-521-48042-0.

5. Chai, G.; Nilsson, J.O.; Boström, M.; Högberg, J.; Forsberg, U. Advanced Heat Resistant Austenitic Stainless Steels. In Advanced Steels: The recent scenario in steel science and technology; Weng, Y., Dong, H., Gan, Y., Eds.; Springer-Verlag GmbH: Heidelberg, Germany, 2011; pp. 385-396, ISBN 978-3-319-19165-2.

6. Intiso, L.; Johansson, L.G.; Canovic, S.; Bellini, S.; Svensson, J.E.; Halvarsson, M. Oxidation Behaviour of Sanicro $25(42 \mathrm{Fe} 22 \mathrm{Cr} 25 \mathrm{NiWCuNbN})$ in $\mathrm{O}_{2} / \mathrm{H}_{2} \mathrm{O}$ Mixture at $600{ }^{\circ} \mathrm{C}$. Oxid. Met. 2012, 77, 209-235. [CrossRef]

7. Intiso, L.; Johansson, L.G.; Svensson, J.E.; Halvarsson, M. Oxidation of Sanicro 25 (42Fe22Cr25NiWCuNbN) in $\mathrm{O}_{2}$ and $\mathrm{O}_{2}+\mathrm{H}_{2} \mathrm{O}$ Environments at $600-750{ }^{\circ} \mathrm{C}$. Oxid. Met. 2015, 83, 367-391. [CrossRef]

8. Zurek, J.; Yang, S.M.; Lin, D.Y.; Hüttel, T.; Singheiser, L.; Quadakkers, W.J. Microstructural stability and oxidation behavior of Sanicro 25 during long-term steam exposure in the temperature range $600-750{ }^{\circ} \mathrm{C}$. Mater. Corros. 2015, 66, 315-327. [CrossRef]

9. Rutkowski, B.; Gil, A.; Czyrska-Filemonowicz, A. Microstructure and chemical composition of the oxide scale formed on the Sanicro 25 steel tubes after fireside corrosion. Corrosion Sci. 2016, 102, 373-383. [CrossRef]

10. Rutkowski, B.; Galanis, A.S.; Gil, A.; Czyrska-Filemonowicz, A. A novel approach to the characterization of thin oxide layers. Mater. Lett. 2016, 173, 235-238. [CrossRef]

11. Allen, G.C.; Tempest, P.A.; Tyler, J.W.; Wild, R.K. Oxidation behavior of $20 \% \mathrm{Cr} / 25 \% \mathrm{Ni} / \mathrm{Nb}$ stabilized stainless steel in $\mathrm{CO}_{2}$ environments. Oxid. Met. 1984, 21, 187-203. [CrossRef]

12. Tyler, J.W. Characterization of the initial oxide formed on annealed and unannealed $20 \mathrm{Cr}-25 \mathrm{Ni}-\mathrm{Nb}$-stabilized steel in 50 torr $\mathrm{CO}_{2}$ at 973 K. Oxid. Met. 1985, 24, 149-176. [CrossRef]

13. Huang, S.Y.; Kuo, J.C.; Tsai, W.T.; Lin, D.Y.; Pan, Y.T. Effect of Niobium on Microstructure and Precipitation in As-annealed Sanicro 25 Steel. Ironmak. Steelmak. 2018. [CrossRef]

14. Lobb, R.C.; Evans, H.E. A determination of the chromium concentration for 'healing' layer formation during the oxidation of chromium-depleted 20Cr-25Ni-Nb stainless steel. Corrosion Sci. 1984, 24, 385-396. [CrossRef]

15. Ledjeff, K.; Rahmel, A.; Schorr, M. Influence of Metal Grain Growth on the Oxidation Behavior of a $25 \mathrm{Cr}-20 \mathrm{Ni}$ Steel. Oxid. Met. 1981, 15, 485-493. [CrossRef]

16. Trindade, V.B.; Krupp, U.; Hanjari, B.Z.; Yang, S.; Christ, H.J. Effect of alloy grain size on the high-temperature oxidation behavior of the austenitic steel TP 347. J. Mater. Res. 2005, 8, 371-375. [CrossRef]

17. Kim, J.H.; Kim, D.I.; Suwas, S.; Fleury, E.; Yi, K.W. Grain-Size Effects on the High-Temperature Oxidation of Modified 304 Austenitic Stainless Steel. Oxid. Met. 2013, 79, 239-247. [CrossRef]

18. Peng, X.; Yan, J.; Zhou, Y.; Wang, F. Effect of grain refinement on the resistance of 304 stainless steel to breakaway oxidation in wet air. Acta Mater. 2005, 53, 5079-5088. [CrossRef]

19. Wu, Q.; Zhang, J.; Sun, Y. Oxidation behavior of TiC particle-reinforced 304 stainless steel. Corrosion Sci. 2010, 52, 1003-1010. [CrossRef]

20. Yuan, J.; Wang, W.; Zhu, S.L.; Wang, F.H. Oxidation Behavior of Super 304H Steel in Steam at 700-900 ${ }^{\circ} \mathrm{C}$. J. Chin. Soc. Corros. Prot. 2014, 34, 218-224. 
21. Birosca, S.; Dingley, D.; Higginson, R.L. Microstructural and microtextural characterization of oxide scale on steel using electron backscatter diffraction. J. Microsc. 2003, 213, 235-240. [CrossRef]

22. West, G.D.; Birosca, S.; Higginson, R.L. Phase determination and microstructure of oxide scales formed on steel at high temperature. J. Microsc. 2003, 217, 122-129. [CrossRef]

23. Higginson, R.L.; Jepson, M.A.E.; West, G.D. Use of EBSD to Characterise high temperature oxides formed on low alloy and stainless steels. Mater. Sci. Technol. 2006, 22, 1325-1332. [CrossRef]

24. Kim, J.H.; Kim, D.I.; Shim, J.H.; Yi, K.W. Investigation into the high temperature oxidation of Cu-bearing austenitic stainless steel using simultaneous electron backscatter diffraction-energy dispersive spectroscopy analysis. Corrosion Sci. 2013, 77, 397-402. [CrossRef]

25. Hart, E.W. On the role of dislocations in bulk diffusion. Acta Metallurgica 1957, 5, 597. [CrossRef]

26. Smeltzer, W.W.; Haering, R.R.; Kirkaldy, J.S. Oxidation of metals by short circuit and lattice diffusion of oxygen. Acta Metallurgica 1961, 9, 880-885. [CrossRef]

27. Herzig, C.; Mishin, Y. Grain Boundary Diffusion in Metals. In Diffusion in condensed matter: Methods, materials, models; Heitjans, P., Kärger, J., Eds.; Springer Science \& Business Media: Berlin, Germany, 2006; pp. 336-366, ISBN 978-3-540-30970-3.

28. Wind, R.K. High temperature oxidation of austenitic stainless steel in low oxygen pressure. Corrosion Sci. 1977, 17, 87-104. [CrossRef]

29. Saeguas, F.; Lee, L. Oxidation of Iron-aluminum alloys in the range 500-1000 ${ }^{\circ}$ C. Corrosion 1966, 22, $168-177$. [CrossRef]

30. Tomaszewicz, P.; Wallwork, G.R. Observations of nodule growth during the oxidation of pure binary iron-aluminum alloys. Oxid. Met. 1983, 19, 165-185. [CrossRef]

31. Tomaszewicz, P.; Wallwork, G.R. The oxidation of high-purity iron-chromium-aluminum alloys at $800{ }^{\circ} \mathrm{C}$. Oxid. Met. 1983, 20, 75-109. [CrossRef]

32. Jackson, P.R.S.; Wallwork, G.R. High temperature oxidation of iron-manganese-aluminum based alloys. Oxid. Met. 1984, 21, 135-170. [CrossRef]

33. Pint, B.A.; Wright, I.G. Long-term high temperature oxidation behavior of ODS ferritics. J. Nucl. Mater. 2002, 307-311, 763-768. [CrossRef]

34. Zhang, Z.G.; Hou, P.Y.; Gesmundo, F.; Niu, Y. Effect of surface roughness on the development of protective $\mathrm{Al}_{2} \mathrm{O}_{3}$ on Fe-10Al (at.\%) alloys containing 0-10 at.\% Cr. Appl. Surf. Sci. 2006, 253, 881-888. [CrossRef]

35. Wood, G.C.; Whittle, D.P. The mechanism of breakthrough of protective chromium oxide scales on $\mathrm{Fe}-\mathrm{Cr}$ alloys. Corrosion Sci. 1967, 7, 771-782. [CrossRef]

36. Wood, G.C. High-Temperature Oxidation of Alloys. Oxid. Met. 1970, 2, 11-57. [CrossRef]

37. Marasco, A.L.; Young, D.J. The oxidation of Iron-Chromium-Manganese alloys at $900{ }^{\circ}$ C. Oxid. Met. 1991, 36, 157-174. [CrossRef]

38. Caplan, D.; Sproule, G.I. Effect of oxide grain structure on the high-temperature oxidation of Cr. Oxid. Met. 1975, 9, 459-472. [CrossRef]

39. Atkinson, H.V. A review of the role of short-circuit diffusion in the oxidation of nickel, chromium, and nickel-chromium alloys. Oxid. Met. 1985, 24, 117-197. [CrossRef]

(C) 2019 by the authors. Licensee MDPI, Basel, Switzerland. This article is an open access article distributed under the terms and conditions of the Creative Commons Attribution (CC BY) license (http://creativecommons.org/licenses/by/4.0/). 